Original Article

\title{
GC-MS BASED CHEMICAL PROFILING AND EVALUATION OF ANTIOXIDANT POTENTIAL OF LEAVES AND STEMS OF ALTERNANTHERA SESSILIS RED FROM SABAH, MALAYSIA
}

\author{
MOHAMMAD SHAHEEN KHAN ${ }^{*}$, SAMINA KHAN YUSUFZAI' ${ }^{2}$,IM YI YING' ${ }^{1}$, WAN ZULNASHRIQ1 \\ ${ }^{1 *}$ Industrial Chemistry Programme, Faculty of Science and Natural Resources, Universiti Malaysia Sabah, 88400 Kota Kinabalu, Sabah, \\ Malaysia, ${ }^{2}$ School of Industrial Technology, Universiti Sains Malaysia, 11800 Minden, Pulau Penang, Malaysia \\ Email: shaheenchem@gmail.com
}

Received: 08 Feb 2018 Revised and Accepted: 06 Jun 2018

\begin{abstract}
Objective: The aim of the current study was to determine the chemical composition of the leaves and stem of Alternanthera sessilis via GC-MS analysis and evaluating their total phenolic content (TPC), total flavonoid content (TFC) and antioxidant activity (AA).

Methods: Determination of AA was carried out by 2,2-diphenyl-1-picrylhydrazyl (DPPH) radical scavenging method. Chemical profiling of leaves and stem was conducted via GC-MS analysis of methanol and hexane extracts, which resulted in the identification of different types of low and high molecular weight compounds consisting of carbohydrates, fatty acid and vitamins. TPC and TFC ws determined by the spectroscopic method and aluminium chloride calorimetric method.

Results: Among all the extracts, methanolic leaf extract exhibited highest DPPH radical scavenging activity with $\mathrm{IC}_{50}$ value of $0.194 \pm 0.003 \mathrm{mg} / \mathrm{ml}$, followed by methanolic stem extract $(0.470 \pm 0.006 \mathrm{mg} / \mathrm{ml})$, hexanolic leaf extract $(0.786 \pm 0.002 \mathrm{mg} / \mathrm{ml})$ and hexanolic stem extract $(2.026 \pm 0.003$ $\mathrm{mg} / \mathrm{ml}$ ), respectively. Butylated hydroxytoluene (BHT) used as the positive control showed IC 50 value of $0.037 \pm 0.002 \mathrm{mg} / \mathrm{ml}$. The results suggested that the crudes extracts of Alternanthera sessilis red leaves and stems exhibited good AA. The TPC and TFC of leaves were determined by using methanol and dichloromethane (DCM) as extracting solvents and was estimated higher for methanolic extract (TFC=142.7 $\pm 0.0003 \mathrm{mg}$ QE/g;
\end{abstract} TPC=279.8 $\pm 0.0002 \mathrm{mg} \mathrm{GAE} / \mathrm{g}$ ). The AA was also reported to be higher for methanolic leaf extract which was $0.194 \mathrm{mg} / \mathrm{ml}$.

Conclusion: TPC was found to be more than TFC. Methanolic extract (highly polar) was reported to display higher TPC and AA when compared to DCM. Among the methanolic and hexanolic extracts of leaves and stem, the AA was reported highest for the methanolic leaf extract.

Keywords: Alternanthera sessilis, Total phenolics, Total flavonoids, DPPH radical scavanging activity, BHT, GC-MS analysis

(c) 2018 The Authors. Published by Innovare Academic Sciences Pvt Ltd. This is an open access article under the CC BY license (http://creativecommons.org/licenses/by/4.0/) DOI: http://dx.doi.org/10.22159/ijpps.2018v10i7.25204

\section{INTRODUCTION}

Tropical rainforests are among the biggest attractions of Malaysia. It is the land of some of the dense rainforests of the world. These rainforests are home to many creatures and pharmacologically important plants that are rich in various medicinal properties [1]. Around 2,000 plants species found here have therapeutic characteristics and can be use in traditional treatment [2]. Most of the medicinal plants which are mean to cure daily ailments are reported to have antioxidant properties which are beneficial to health [3]. Different parts of the plants such as leaves, flowers, seed and roots were reported to have important biological and pharmacological activities, such as antioxidant, anti-allergic, antibiotic and anticarcinogenic properties. According to research, almost $80 \%$ of people globally used herbal medication as health care due to the potency of herbal medication [4]. Natural antioxidants from medicinal plants sources are always popular in the food industries. They can be added to variety of foods for the prevention of oxidation via inhibiting the initiation of the radical chain reaction and also propagation steps resulting in the termination of the oxidation reaction processes [5]. The popularity of natural antioxidants is growing based on the fact that few synthetic antioxidants such as butylated hydroxyanisole (BHA) and BHT are now suspected to be oxidation reaction processes. The popularity of natural antioxidants is growing based on the fact that few synthetic antioxidants such as BHA and BHT are now suspected to be harmful to human health as they confer some degree of carcinogenicity. Therefore, the surge for natural antioxidants has ever since increased. Phenolic compound derivatives became an exciting topic within this era because of their highly antioxidative effect. The polyphenols prevents various diseases and anti-aging [6]. Vegetables, fruits and tea are believed to account mainly for antioxidant activity of many plants by distributing the phenolic compounds with antioxidant activity in it [7]. Moreover, due to the higher antioxidant activity, investigation of phenolic compounds in medicinal herbs have become more imperative in the past few years [8]. Flavonoids have been of particular interest because of their multiple roles in plants and their benefits in human health [9]. The main dietary sources of flavonoids along with wine and tea are fruits and vegetables [10]. Experiments have proven that flavonoids affect the heart and circulatory system and also strengthens the capillaries. They are often referred to as 'biological stress modifiers' since they serve as protection against environmental stress [11]. They are also known to have synergistic effects with ascorbic acid. Their protective actions are mainly due to membrane stabilizing and antioxidant effects.

Alternanthera sessilis red belongs to the family Amaranthaceae, which grows under a variety of soil and climatic conditions [12]. In Malaysia it is commonly known under various names such as keremak, pudoh rumput aoh and serapat, depending upon the local areas. Wet soil condition is found to be the best for its growth, but it is habitant for marshy areas and wetlands [13]. Several therapeutic benefits of $A$. sessilis have been investigated which includes antidiabetic, anti-inflammatory, cytotoxic effect toward pancreatic cancer lines and free radical scavenging activity [14]. The main aim of the present study was to determine the total phenolic content, total flavonoid concentration and antioxidant activity of various solvent extracts obtained from the plant $A$. sessilis. All these organic solvent extracts were also subjected to phytochemical screening.

\section{MATERIALS AND METHODS}

\section{Chemicals, reagents and instruments}

Follin-Ciocalteu phenol reagent, BHT, DPPH, aluminium chloride, quercetin, ascorbic acid, gallic acid and sodium carbonate $\left(\mathrm{Na}_{2} \mathrm{CO}_{3}\right)$ were obtained from Sigma-Aldrich. Hexane, DCM and methanol were purchased from Merck. All chemicals were of analytical grade 
and used without any further purification. The GC-MS analysis was conducted on a Perkin Elmer Clarus 500, GC-MS spectrometer equipped with VF-5 MS fused silica capillary column of $30 \mathrm{~m} \times 0.25$ i.d. and $0.25 \mu \mathrm{m}$ film thickness. Perkin Elmer Lamda $20 \mathrm{UV}$-Vis spectrophotometer was used to measure the absorbance for the determination of AA, TPC and TFC of all the crude extracts.

\section{Collection and preparation of plant material}

The medicinal plant Alternanthera sessilis red was bought from Orchard De Villa which is located at Luyang Kota Kinabalu, Sabah, Malaysia. The botanical identification and confirmation were achieved by Borneo Herbarium, Universiti Malaysia Sabah where a voucher specimen 00001-LPK was deposited in the herbarium. The fresh plant, which was in good condition, was thoroughly washed with water. The leaves were collected and dissected in small pieces and dried under shades inside the laboratory benches at ambient temperature for one week to ensure it is dried completely. About 1 $\mathrm{kg}$ leaves were pulverized in a grinder for $3 \mathrm{~min}$ and stored in dark bags to protect from humidity and light, prior to analysis.

\section{Preparation of crude extract}

The dried leaves powder $(200 \mathrm{~g})$ was extracted with methanol using Soxhlet extraction method at room temperature. The methanolic extract was recovered by evaporating the solvent by vacuum rotator evaporator. This crude extract was further diluted with water and subsequently extracted with hexane and dichloromethane to get their respective residual fractions. These fractions were filtered using Whatman's filter paper and then evaporated under reduced pressure via rotary evaporator in order to obtain the crude extracts. The extraction processes were repeated in triplicate. After solvent evaporation, all the crude extracts were weighed and kept for further usage in caped vials at $4^{\circ} \mathrm{C}$.

\section{GC-MS analysis of crude extract}

The samples of Alternanthera sessilis red leaves ans stems were prepared in methanol and hexane and analyzed by injecting into GC-
MS with a split injector at $300{ }^{\circ} \mathrm{C}$. The VF-5 MS fused silica capillary column $(30 \mathrm{~m} \times 0.25 \mathrm{~mm} \times 0.25 \mu \mathrm{m})$ was employed. The temperature programme was $50{ }^{\circ} \mathrm{C}$, held for $10 \mathrm{~min}$, increased at 3 ${ }^{\circ} \mathrm{C} / \mathrm{min}$ to $250^{\circ} \mathrm{C}$ and finally hold for $10 \mathrm{~min}$. Inert helium gas was employed as a carrier gas at a constant flow rate of $1.0 \mathrm{ml} / \mathrm{min}$. The compounds were identified by comparison of their retention indices (RI) with those provided in National Institute of Standards and Technology (NIST) library. Identification was assumed when a good match of RI was achieved.

\section{Determination of TPC}

The TPC was determined using the spectroscopic method as described by Ainsworth and Gillespie, 2007 [15]. The reaction mixture was prepared by mixing $1 \mathrm{ml}$ plant extracts $(1 \mathrm{mg} / \mathrm{ml}), 1$ $\mathrm{ml}$ of $10 \%$ Folin-Ciocalteu's reagent dissolved in $13 \mathrm{ml}$ of deionized water followed by the addition of $5 \mathrm{ml}$ of $7 \% \mathrm{Na}_{2} \mathrm{CO}_{3}$ solution. The mixture was mixed thoroughly and kept in the dark at room temperature for $2 \mathrm{~h}$. The blank solution was also prepared. The absorbance was recorded using UV-Vis spectrometer at $760 \mathrm{~nm}$. All the analysis was repeated three times and the mean value of absorbance was obtained. TPC was determined by extrapolating calibration line which was construed by the gallic acid solution. The TPC was expressed as gallic acid equivalent (mg GAE) per gram of the dried sample.

\section{Determination of TFC}

The TFC of the Alternanthera sessilis Red was determined by using aluminium chloride calorimetric method based on the methodology reported by Afify et al. [16]. $0.5 \mathrm{ml}$ of sample $(1 \mathrm{mg} / \mathrm{ml})$ was mixed with $1 \mathrm{ml}$ of $10 \%$ aluminium chloride, $1 \mathrm{ml}$ of potassium acetate $(1 \mathrm{M})$ and $2.5 \mathrm{ml}$ of distilled water. Quercetin was used as the internal standard. The absorbance of the mixtures was measured at $415 \mathrm{~nm}$ by using UV-spectrophotometer. The TFC was expressed in terms of quercetin equivalent (mg QE/g of sample). All the analyses were repeated three times and the mean value of absorbance was obtained.

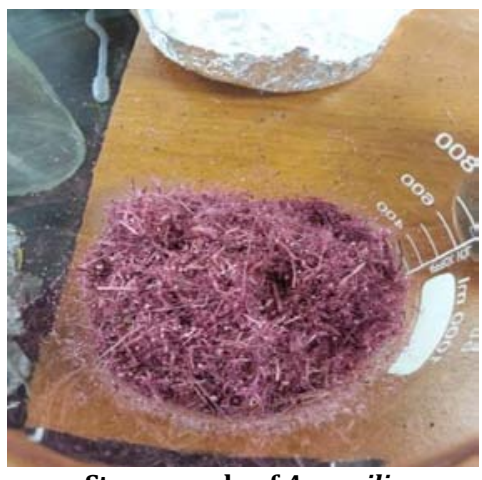

Stem sample of $A$. sessilis

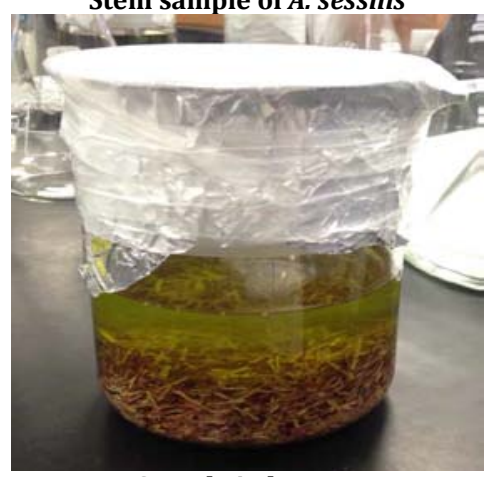

Sample in hexane

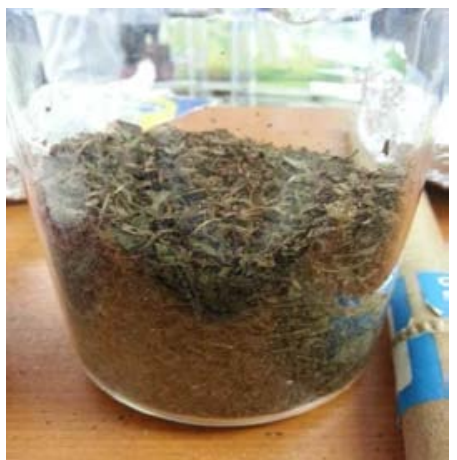

Leaves sample of $\boldsymbol{A}$. sessilis

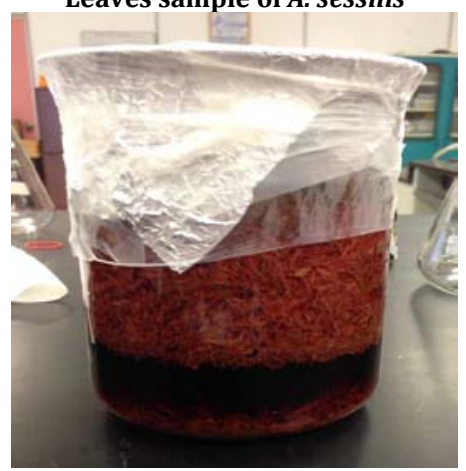

Sample in methanol

Fig. 1: Soaked and dissected plant samples in methanol and hexane

In order to study GC-MS based chemical profiling, the leaves and stem of Alternanthera sessilis red were extracted with hexane and methanol (fig. 1). The initial weight of the sample used was $300 \mathrm{~g}$ for each viz. leaves and stem. The highest percentage yield of solid residue was obtained for methanolic stem extract (table 1). 


\section{DPPH radical scavenging activity}

The AA of all the four extracts were quantitatively assessed on the basis of free radical scavenging activity of stable DPPH radical according to the reported method of Brand-Williams et al. $1 \mathrm{ml}$ of plant extract solution of various concentrations, ranging from $0.05-$ $0.20 \mathrm{mg} / \mathrm{ml}$ was mixed with $1 \mathrm{ml}$ of $0.5 \mathrm{mmol} \mathrm{DPPH}$ solution in methanol. Incubation of the resulting solution was carried out for 30 min in dark room at $37^{\circ} \mathrm{C}$. BHT was used as the positive control under the same assay condition. The absorbance was measured calorimetrically at $517 \mathrm{~nm}$. The experiments were carried out in triplicate. The percentage inhibition was calculated using the following formula.

$$
\% \text { of radical scavenging activity }=100 \times \frac{A_{\text {control }}-A_{\text {sample }}}{\mathrm{A}_{\text {controI }}}
$$

Here, Ao is the absorbance of the control (no sample, DPPH solution only) and As is the absorbance in the presence of the sample.

\section{RESULTS AND DISCUSSION}

Table 1: The percentage yield of extracts obtained from the solid residue of plant material

\begin{tabular}{lll}
\hline Extracts & Weight of crude extract (g) & Yield (\%) \\
\hline Methanol leaves & 9.48 & 3.16 \\
Methanol stem & 19.77 & 6.59 \\
Hexane leaves & 13.18 & 4.39 \\
Hexane stem & 10.26 & 3.42 \\
\hline
\end{tabular}

The methanolic and hexanolic crude extracts were analyzed by using GCMS which led to the identification of different organic compounds of polar and nonpolar in nature, respectively. The identified chemical compounds are listed in table 2, table 3, table 4 and table 5 according to their elution order on a VF-5 capillary column. The major chemical compounds found in the hexanolic leaf extract were, $(Z, Z)-9,12-$ Octadecadienoic acid (25.33 \%), Vitamin A aldehyde (11.94 \%) and 12bromododecanoic acid (11.37\%), respectively. The major chemical compounds found in hexanolic leaf extract were hexamethyl cyclotrisiloxane (14.37\%), 10,13-dimethyl tetradecanoic acid, methyl ester (13.91 \%), (Z,Z,Z)-9,12,15-octadecatrienoicacid methyl ester, $(10.94 \%), \quad$ trimethyl-[4-(1,1,3,3,-tetramethylbutyl)phenoxy]silane $(10.39 \%)$ and hexamethylcyclotrisiloxane-1-monolinoleoyl glycerol trimethylsilyl ether $(9.18 \%)$. The methanolic stem extract led to the identification of methyl-2-O-methyl- $\alpha$ - $D$-xylofuranoside (30.47 \%), followed by 2-(diethyl boryl oxy)-ethanethiol, (20.21\%) and tetrahydro2,5-dimethoxy-furan $(12.11 \%)$ as major compounds whereas the major compounds in methanolic leaf extract were 2,2-dimethyl-1,3propanediol (41.14\%), 1,3-dimethoxy-3-methyl-2-pentanone (14.22\%) and 2-(1-methylpropyl)cyclopentanone (11.49\%).

Table 2: Chemical composition of hexanolic crude extract of stem of Alternanthera sessilis red

\begin{tabular}{|c|c|c|c|c|c|}
\hline No & Ret. time & Name of compounds & Molecular formula & M. W & Peak area $\%$ \\
\hline 1 & 2.02 & 2-Methyl-2-decanol & $\mathrm{C}_{11} \mathrm{H}_{24} \mathrm{O}$ & 172 & 0.07 \\
\hline 2 & 2.77 & 2,3,4 Trimethylpentanoic acid & $\mathrm{C}_{8} \mathrm{H}_{16} \mathrm{O}_{2}$ & 144 & 0.80 \\
\hline 3 & 3.24 & 1,3-Dimethoxy-3-methyl-2-pentanone & $\mathrm{C}_{8} \mathrm{H}_{16} \mathrm{O}_{3}$ & 160 & 3.69 \\
\hline 4 & 4.93 & 3-(2-Methoxyethoxymethoxy)-2-methylpentan-1-ol & $\mathrm{C}_{10} \mathrm{H}_{22} \mathrm{O}_{4}$ & 206 & 1.81 \\
\hline 5 & 5.11 & 1,1-Diethoxydecane & $\mathrm{C}_{14} \mathrm{H}_{30} \mathrm{O}_{2}$ & 230 & 1.27 \\
\hline 6 & 10.10 & 1-Fluorododecane & $\mathrm{C}_{12} \mathrm{H}_{25} \mathrm{~F}$ & 188 & 1.33 \\
\hline 7 & 26.56 & Cyclohexane-1,3-dione,2-allylaminomethylene-5, 5-dimethyl- & $\mathrm{C}_{12} \mathrm{H}_{17} \mathrm{NO}_{2}$ & 207 & 0.19 \\
\hline 8 & 30.84 & 1,1,1,3,5,5,7,7,7-Nonamethyl-3-(trimethylsiloxy)tetrasiloxane & $\mathrm{C}_{12} \mathrm{H}_{36} \mathrm{O}_{4} \mathrm{Si}_{5}$ & 384 & 2.00 \\
\hline 9 & 31.55 & 1-O-(10-Undecenyl)- $\beta$ - $D$-Mannofuranoside & $\mathrm{C}_{17} \mathrm{H}_{32} \mathrm{O}_{6}$ & 332 & 0.48 \\
\hline 10 & 37.47 & Octadecanoic acid,phenylmethyl ester & $\mathrm{C}_{25} \mathrm{H}_{42} \mathrm{O}_{2}$ & 374 & 0.84 \\
\hline 11 & 41.84 & 3-Methyl-2-(2-oxopropyl)furan & $\mathrm{C}_{8} \mathrm{H}_{10} \mathrm{O}_{2}$ & 138 & 1.32 \\
\hline 12 & 42.06 & Phthalic acid, bis(7-methyloctyl) ester & $\mathrm{C}_{26} \mathrm{H}_{42} \mathrm{O}_{4}$ & 418 & 0.86 \\
\hline 13 & 42.74 & Phthalic acid, isobutyl 2-methylallyl ester & $\mathrm{C}_{16} \mathrm{H}_{20} \mathrm{O}_{4}$ & 276 & 0.64 \\
\hline 14 & 43.03 & Tetradecanoic acid, 10,13-dimethyl-, methyl ester & $\mathrm{C}_{17} \mathrm{H}_{34} \mathrm{O}_{2}$ & 270 & 3.16 \\
\hline 15 & 43.47 & 12-Bromododecanoic acid & $\mathrm{C}_{12} \mathrm{H}_{23} \mathrm{BrO}_{2}$ & 278 & 11.37 \\
\hline 16 & 43.87 & 10-Bromodecanoic acid, ethyl ester & $\mathrm{C}_{12} \mathrm{H}_{23} \mathrm{BrO}_{2}$ & 278 & 3.79 \\
\hline 17 & 44.34 & 1-Fluoro-Dodecane & $\mathrm{C}_{12} \mathrm{H}_{25} \mathrm{~F}$ & 188 & 2.08 \\
\hline 18 & 44.96 & 6,11-Eicosadienoic acid, methyl ester & $\mathrm{C}_{21} \mathrm{H}_{38} \mathrm{O}_{2}$ & 322 & 4.54 \\
\hline 19 & 45.03 & $(Z, Z, Z)-9,12,15$-Octadecatrienoic acid, methyl ester & $\mathrm{C}_{19} \mathrm{H}_{32} \mathrm{O}_{2}$ & 292 & 2.73 \\
\hline 20 & 45.15 & Phytol & $\mathrm{C}_{20} \mathrm{H}_{40} \mathrm{O}$ & 296 & 5.50 \\
\hline 21 & 45.36 & 7-Pentyl-Bicyclo[4.1.0]heptane & $\mathrm{C}_{12} \mathrm{H}_{22}$ & 166 & 4.55 \\
\hline 22 & 45.43 & $(Z, Z)-9,12,-$ Octadecadienoic acid & $\mathrm{C}_{18} \mathrm{H}_{32} \mathrm{O}_{2}$ & 280 & 25.33 \\
\hline 23 & 45.71 & $Z, Z-6,28$-Heptatriactontadien-2-one & $\mathrm{C}_{37} \mathrm{H}_{70} \mathrm{O}$ & 530 & 8.26 \\
\hline 24 & 45.82 & Vitamin A aldehyde & $\mathrm{C}_{20} \mathrm{H}_{28} \mathrm{O}$ & 284 & 11.94 \\
\hline
\end{tabular}

The result of total TPC was estimated by using Folin-Ciocalteu reagent. The phenolic content in plant extracts of Alternanthera sessilis red is expressed as milligram of Gallic acid equivalent (GAE) per gram of dry weight of extract, which is solvent dependent. The higher the polarity of solvent the more will be the TPC and TFC in the extract (table 7). Therefore, two polar solvents were choosen in order to obtain the TPC and TFC i.e. methanol and DCM. The flavonoid concentration expressed as quercetin equivalent was determined by using aluminium chloride method. Higher concentration of flavonoids was found in the methanol extract $(142 \pm 0.0003)$ followed by the dichloromethane $(79.8 \pm 0.0001)$. The percentage yield obtained for both the extraction solvents are given in table 6, which significantly depends on the polarity of the solvent The more is the polarity, the higher is the yield. 
Table 3: Chemical composition of hexanolic crude extract of leaves of Alternanthera sessilis red

\begin{tabular}{|c|c|c|c|c|c|}
\hline No & Ret. time & Name of compounds & Molecular formula & M. W & Peak area \% \\
\hline 1 & 2.13 & 1-Hexen-4-ol, 1-chloro-3,5-dimethyl- & $\mathrm{C}_{8} \mathrm{H}_{15} \mathrm{OCl}$ & 162 & 1.62 \\
\hline 2 & 2.29 & Phtytol & $\mathrm{C}_{20} \mathrm{H}_{40} \mathrm{O}$ & 296 & 0.38 \\
\hline 3 & 2.50 & 5-Hydroxy-4-methyl-6-hepten-3-one & $\mathrm{C}_{8} \mathrm{H}_{14} \mathrm{O}_{2}$ & 142 & 0.72 \\
\hline 4 & 2.75 & 2,3,4-Trimethylpentanoic acid & $\mathrm{C}_{8} \mathrm{H}_{16} \mathrm{O}_{2}$ & 144 & 2.25 \\
\hline 5 & 3.21 & Methyl 2-O-methyl- $\alpha$ - $D$-xylofuranoside & $\mathrm{C}_{7} \mathrm{H}_{14} \mathrm{O}_{5}$ & 178 & 8.99 \\
\hline 6 & 3.49 & Methyl 2,4-dimethylhexanoate & $\mathrm{C}_{9} \mathrm{H}_{18} \mathrm{O}_{2}$ & 158 & 0.76 \\
\hline 7 & 4.89 & Hexamethyl-Cyclotrisiloxane & $\mathrm{C}_{6} \mathrm{H}_{18} \mathrm{O}_{3} \mathrm{Si}_{3}$ & 222 & 14.37 \\
\hline 8 & 5.05 & Trimethyl[4-(1,1,3,3,-tetramethylbutyl)phenoxy]silane & $\mathrm{C}_{17} \mathrm{H}_{30} \mathrm{OSi}$ & 278 & 10.39 \\
\hline 9 & 30.83 & 1,1,1,3,5,5,7,7,7-Nonamethyl-3-(trimethylsiloxy) tetrasiloxane & $\mathrm{C}_{12} \mathrm{H}_{36} \mathrm{O}_{4} \mathrm{Si}_{5}$ & 384 & 3.45 \\
\hline 10 & 34.98 & Isophytol & $\mathrm{C}_{20} \mathrm{H}_{40} \mathrm{O}$ & 296 & 1.86 \\
\hline 11 & 42.94 & 1,10-Hexadecanediol & $\mathrm{C}_{16} \mathrm{H}_{34} \mathrm{O}_{2}$ & 258 & 2.47 \\
\hline 12 & 43.01 & 10,13-Dimethyl-Tetradecanoic acid, methyl ester & $\mathrm{C}_{17} \mathrm{H}_{34} \mathrm{O}_{2}$ & 270 & 13.91 \\
\hline 13 & 43.78 & Z,Z-6,28-Heptatriactontadien-2-one & $\mathrm{C}_{37} \mathrm{H}_{70} \mathrm{O}$ & 530 & 1.64 \\
\hline 14 & 43.91 & Methyl 4-(2-methyl-2-propen-1-yl)-3-cyclohexene-1-carboxylate & $\mathrm{C}_{12} \mathrm{H}_{18} \mathrm{O}_{2}$ & 194 & 1.46 \\
\hline 15 & 44.95 & $(Z, Z)-9,12$-Octadecadien-1-ol & $\mathrm{C}_{18} \mathrm{H}_{34} \mathrm{O}$ & 266 & 5.96 \\
\hline 16 & 45.02 & $(Z, Z, Z)-9,12,15$-Octadecatrienoic acid, methyl ester & $\mathrm{C}_{19} \mathrm{H}_{32} \mathrm{O}_{2}$ & 292 & 10.94 \\
\hline 17 & 45.14 & 1-Pentatriacontanol & $\mathrm{C}_{35} \mathrm{H}_{72} \mathrm{O}$ & 508 & 5.06 \\
\hline 18 & 45.30 & Heptacosanoic acid, 25-methyl-, methyl ester & $\mathrm{C}_{29} \mathrm{H}_{58} \mathrm{O}_{2}$ & 438 & 1.55 \\
\hline 19 & 45.78 & 1-Monolinoleoylglycerol trimethylsilyl ether & $\mathrm{C}_{27} \mathrm{H}_{54} \mathrm{O}_{4} \mathrm{Si}_{2}$ & 498 & 9.18 \\
\hline 20 & 46.09 & Trimethyl[5-methyl-2-(1-methylethyl)phenoxy]-Silane & $\mathrm{C}_{13} \mathrm{H}_{22} \mathrm{OSi}$ & 222 & 3.05 \\
\hline
\end{tabular}

Table 4: Chemical composition of a methanolic crude extract of stem of Alternanthera sessilis red

\begin{tabular}{|c|c|c|c|c|c|}
\hline No. & Ret. time & Name of compounds & Molecular formula & M. W & Peak area \% \\
\hline 1 & 2.77 & 2,3,4 Trimethyl pentanoic acid & $\mathrm{C}_{8} \mathrm{H}_{16} \mathrm{O}_{2}$ & 144 & 5.77 \\
\hline 2 & 3.24 & Methyl-2-O-methyl- $\alpha$ - $D$-xylofuranoside & $\mathrm{C}_{7} \mathrm{H}_{14} \mathrm{O}_{5}$ & 178 & 30.47 \\
\hline 3 & 4.92 & Furan, tetrahydro-2,5-dimethoxy- & $\mathrm{C}_{6} \mathrm{H}_{12} \mathrm{O}_{3}$ & 132 & 12.11 \\
\hline 4 & 6.42 & Tritetracontane & $\mathrm{C}_{43} \mathrm{H}_{88}$ & 604 & 3.69 \\
\hline 5 & 8.91 & Ethanethiol, 2-(diethylboryloxy)- & $\mathrm{C}_{6} \mathrm{H}_{15} \mathrm{BOS}$ & 146 & 20.21 \\
\hline 6 & 10.07 & 1-fluorododecane & $\mathrm{C}_{12} \mathrm{H}_{25} \mathrm{~F}$ & 188 & 6.13 \\
\hline 7 & 27.46 & Methyl 3-[(1E)-5-hydroxy-1-pentenyl]benzoate & $\mathrm{C}_{13} \mathrm{H}_{16} \mathrm{O}_{3}$ & 220 & 4.96 \\
\hline 8 & 37.88 & $Z, Z-6,28$-Heptatriactontadien-2-one & $\mathrm{C}_{37} \mathrm{H}_{70} \mathrm{O}$ & 530 & 1.02 \\
\hline 9 & 41.12 & 7-Methyl-4-octanol & $\mathrm{C}_{9} \mathrm{H}_{20} \mathrm{O}$ & 144 & 2.39 \\
\hline 10 & 43.43 & 3-Methyl-2-(2-oxopropyl)furan & $\mathrm{C}_{8} \mathrm{H}_{10} \mathrm{O}_{2}$ & 138 & 3.78 \\
\hline
\end{tabular}

Table 5: Chemical composition of a methanolic crude extract of leaves of Alternanthera sessilis red

\begin{tabular}{|c|c|c|c|c|c|}
\hline No. & Ret. time & Name of compounds & Molecular formula & M. W & Peak area \% \\
\hline 1 & 2.15 & Scyllo-inositol & $\mathrm{C}_{6} \mathrm{H}_{12} \mathrm{O}_{6}$ & 180 & 3.33 \\
\hline 2 & 2.24 & 2-(1-Methylpropyl)cyclopentanone & $\mathrm{C}_{9} \mathrm{H}_{16} \mathrm{O}$ & 140 & 11.49 \\
\hline 3 & 2.77 & 2,3,4 Trimethylpentanoic acid & $\mathrm{C}_{8} \mathrm{H}_{16} \mathrm{O}_{2}$ & 144 & 2.76 \\
\hline 4 & 3.24 & 1,3-Dimethoxy-3-methyl-2-pentanone & $\mathrm{C}_{8} \mathrm{H}_{16} \mathrm{O}_{3}$ & 160 & 14.22 \\
\hline 5 & 4.21 & 2,2-Dimethyl-1,3-propanediol & $\mathrm{C}_{5} \mathrm{H}_{12} \mathrm{O}_{2}$ & 104 & 41.14 \\
\hline 7 & 4.93 & 4,4-Dimethoxycyclohexanone & $\mathrm{C}_{8} \mathrm{H}_{14} \mathrm{O}_{3}$ & 158 & 4.60 \\
\hline
\end{tabular}

Table 6: The percentage yield of extracts obtained from solid leaf residue of plant material

\begin{tabular}{ll}
\hline Plant extracts & Percentage yield (\%) \\
\hline Methanol & 2.49 \\
Dichloromethane & 2.45 \\
\hline
\end{tabular}

Table 7: Total phenolic and total flavonoid contents in methanol and DCM extracts of Alternanthera sessilis red leaves

\begin{tabular}{lll}
\hline Plant extracts & Total phenolic contents (mg GAE/g) & Total flavonoid contents (mg QE/g) \\
\hline Methanol & $279.8 \pm 0.0002$ & $142.7 \pm 0.0003$ \\
Dichloromethane & $84.5 \pm 0.0003$ & $79.8 \pm 0.0001$ \\
\hline
\end{tabular}

aData are expressed as mean $\pm S D$, bResults are the mean of triplicate values $(n=3)$

DPPH radical is widely used as a model to determine the scavenging potential of several natural compounds such as phenolics or crude extract of plants [17]. The basic principle of DPPH method is based on the reduction of DPPH in the presence of a hydrogen donating antioxidant. The degree of discoloration indicates the scavenging potential of antioxidant compounds of the extracts. The absorption strength decreases in the presence of a free radical scavenging antioxidant. The leaves and stem of $A$. sessilis red in different organic solvents were tested for their free radical scavenging activity using DPPH assay. The results obtained showed an increase in the percentage inhibition as the concentration increases. The highest percentage inhibition exhibited by BHT was $88.84 \%$. Meanwhile, for the methanolic leaf extract, methanolic stem extract, hexanolic leaf extract and hexanolic stem extract the highest percentage inhibition were $70.81 \%, 53.74 \%$, 
$48.66 \%$ and $40.10 \%$ respectively. The higher is the percentage inhibition, the higher is the AA (fig.2). Furthur, the $\mathrm{IC}_{50}$ value was calculated. IC 50 value is the concentration of sample at which the inhibition percentage reaches $50 \%$. In the case of methanolic extract, the IC 50 was reported to be $0.194 \pm 0.003 \mathrm{mg} / \mathrm{ml}$ and $0.470 \pm 0.006 \mathrm{mg} / \mathrm{ml}$ for leaves and stem extracts, respectively. Whereas, for hexanolic extracts the $\mathrm{IC}_{50}$ was reported to be $0.786 \pm 0.002 \mathrm{mg} / \mathrm{ml}$ for leaf and $2.026 \pm 0.003$ $\mathrm{mg} / \mathrm{ml}$ for stem, respectively. BHT was used as standard had $\mathrm{IC}_{50}$ value of $0.037 \pm 0.002 \mathrm{mg} / \mathrm{ml}$ (fig. 3). The difference in their $\mathrm{IC}_{50}$ value is due to the presence of different phytochemicals in different crude extracts of Alternanthera sessilis red leaves and stem. The lower the $\mathrm{IC}_{50}$ value, the higher the free radical scavenging activity. Therefore, methanolic leaf extract displayed the strongest free radical scavenging properties over the rest three when compared to BHT.

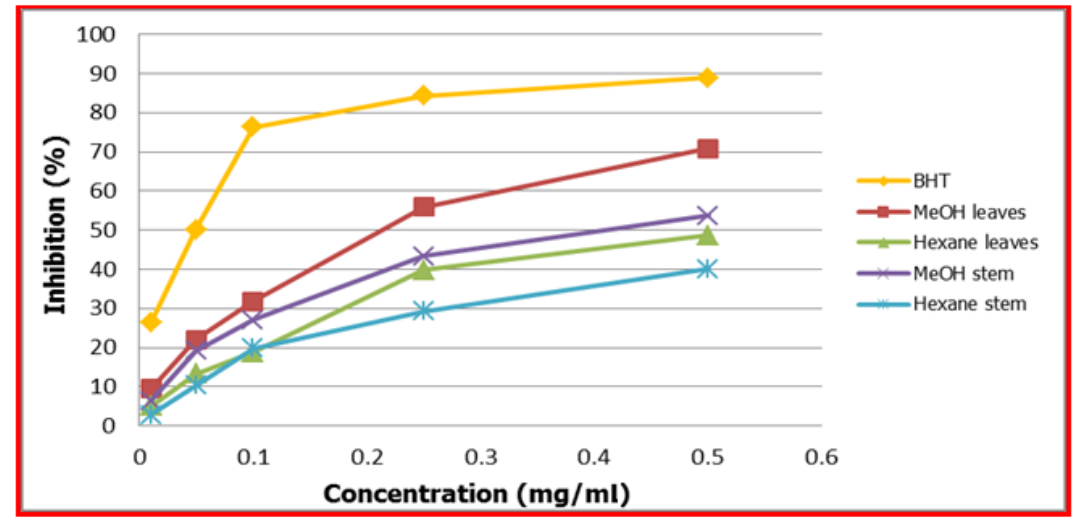

Fig. 2: Percentage inhibition of BHT and various $A$. sessilis red extracts against different concentration, a Results are the mean of triplicate values $(n=3)$

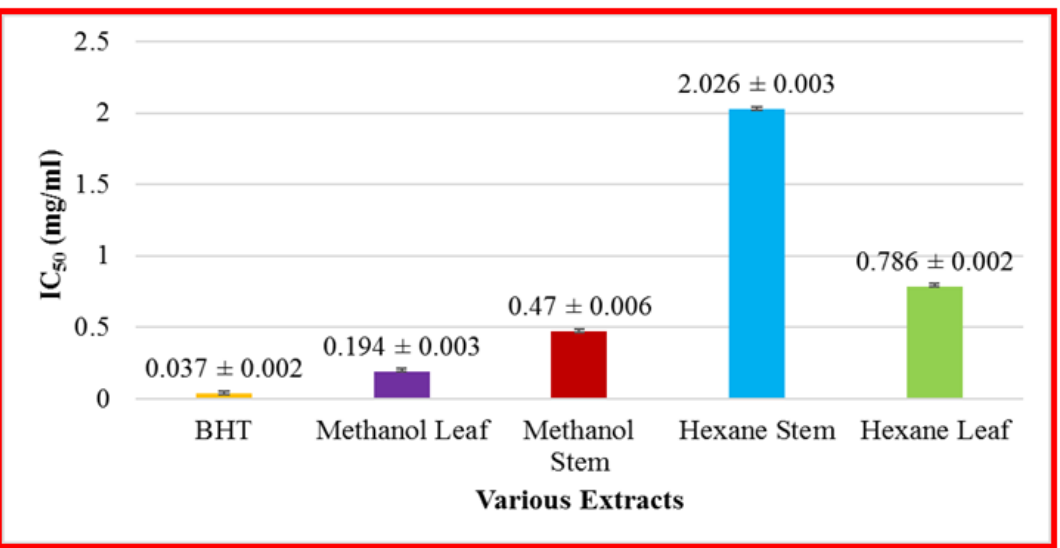

Fig. 3: $\mathrm{IC}_{50}$ value of BHT and various $A$. sessilis red extracts against different concentration, axperiments were run in triplicate ( $\mathrm{n}=3$ ), ${ }^{b}$ Results are reported in mean $\pm S D$

\section{CONCLUSION}

In conclusion, this study shows a higher ratio of total flavonoid content $(142.7 \pm 0.0003 \mathrm{mg} \mathrm{QE} / \mathrm{g})$ and total phenolic content $(279.8 \pm 0.0002 \mathrm{mg} G A E / g)$ in methanol extract followed by DCM extract. The highest AA was reported to be $0.194 \pm 0.003 \mathrm{mg} / \mathrm{ml}$, for strongly polar methanol leaf extract followed by methanol stem extract $(0.470 \pm 0.006 \mathrm{mg} / \mathrm{ml})$, which proves that polar solvent are good extracting solvents for the identification of TPC, TFC as well as free radical scavenging properties.

\section{ACKNOWLEDGEMENT}

The authors thank Faculty of Science and Natural Resources, Universiti Malaysia Sabah (UMS), Kota Kinabalu and School of Industrial Technology, Universiti Sains Malaysia, Pulau Penang, for providing necessary research facilities to carry out the research work. Mohammad Shaheen Khan (MSK) thanks to the Malaysian Government and UMS for the providing research grant SBK03292017 to conduct this work.

\section{AUTHORS CONTRIBUTIONS}

MSK designed the study, the main conceptual ideas and proof outline. LYY, WZ and MSK performed the experiments. SKY worked out almost all of the technical details, performed the numerical calculations for the suggested experiment and took the lead in writing the manuscript.

\section{CONFLICT OF INTERESTS}

The authors declare no conflict of interest

\section{REFERENCES}

1. Kulip J. An ethnobotanical survey of medicinal and other useful plants of Muruts in Sabah, Malaysia. Telopea 2003:10:81-98.

2. Rukayh A. Tumbuhan Liar Berkhasiat Ubatan. Dewan Bahasa dan Pustaka, Kuala Lumpur; 2006.

3. Hossain MA, Shah MD, Gnanaraj C, Iqbal M. In vitro total phenolics, flavonoids contents and antioxidant activity of essential oil, various organic extracts from the leaves of tropical medicinal plant Tetrastigma from Sabah. Asian Pac J Trop Med 2011;4:717-21.

4. WHO. Quality control methods for medicinal plant material; 2008.

5. Nimse SB, Pal D. Free radicals, natural antioxidants, and their reaction mechanisms. RSC Adv 2015;5:27986-8006.

6. Fujita N, Saito Y, Ito T, Mizuguchi H, Endo M, Ogata T. Folinchiocalteu colourimetric analysis using a scanner for rapid 
determination of total polyphenol content in many test samples. Stud Sci Technol 2012;1:139-44.

7. Wu X, Beecher GR, Holden JM, Haytowitz DB, Gebhardt SE, Prior RL. Lipophilic and hydrophilic antioxidant capacities of common foods in the United States. J Agric Food Chem 2004;52:4026-37.

8. Zhu YZ, Huang SH, Tan BK, Sun J, Whiteman M, Zhu YC. Antioxidants in Chinese herbal medicines: a biochemical perspective. Nat Prod Rep 2004;21:478-89.

9. Harborne JB, Williams CA. Advances in flavonoid research since 1992. Phytochem 2000;55:481-504.

10. LH, Jiang YM, Shi J, Tomas-Barberan FA, Datta N, Singanusong $\mathrm{R}$, Chen SS. Flavonoids in food and their health benefits. Plant Foods Hum Nutr 2004;59:113-22.

11. Middleton E. Effect of plant flavonoids on immune and inflammatory cell function. In Flavonoids in the living system. Boston MA. Springer; 1998. p. 175-82.

12. Vinodh KS, Kumar BS. GC-MS analysis of aqueous leaf extract of Alternanterasessilis. Int J Pharm Res Sch 2014;3:382-7.
13. V Vennila, $\mathrm{R}$ Nivetha. Screening the in vitro anthelmintic activity of alternanthera sessilis leaves. World J Pharm Pharm Sci 2015;4:1402-5.

14. Tan KK, Kim KH. Alternanthera sessil is red ethyl acetate fraction exhibits antidiabetic potential on obese type 2 diabetic rats. J Evid Based Complementary Altern Med 2013;2013:845172845179. http://dx.doi.org/10.1155/2013/845172.

15. Ainsworth EA, Gillespie KM. Estimation of total phenolic content and other oxidation substrates in plant tissues using folin-ciocalteu reagent. Nat Protoc 2007;2:875-7.

16. Afify AE, El-Beltagi HS, El-Salam SM, Omran AA. Biochemical changes in phenols, flavonoids, tannins, vitamin $\mathrm{E}, \beta$-carotene and antioxidant activity during soaking of three white sorghum varieties. Asian Pac J Trop Biomed 2012;2:203-9.

17. Veerapur VP, Prabhakar KR, Parihar VK, Kandadi MR, Ramakrishana S, Mishra B, et al. Ficus racemosa stem bark extract: a potent antioxidant and a probable natural radioprotector. J Evid Based Complementary Altern Med 2009;6:317-24. 